\title{
FEATURES OF THE DEVELOPMENT OF ECOLOGICAL SELF-AWARENESS IN ADOLESCENCE
}

\section{Bogdana Zorya ${ }^{1}$}

DOI: https://doi.org/10.30525/978-9934-26-050-6-42

Development of ecological consciousness in adolescence is due to the systemic functioning of subjective personality traits. The concept of «environmental consciousness» requires operationalization, since it is identified or used in parallel with the concept of ecological consciousness. These phenomena are considered as a single indivisible whole, there are no description of their phenomenology, specifics, no given specific definitions of «environmental consciousness».

Ecological consciousness changes and evolves according to normative development of self-consciousness, ecological self-consciousness is an integral reflection of the World by the personality, its place in it, and semantic unity with it. Ecological self-consciousness is awareness of both at the same time and part of the ecosystem, and a unique personality and structure based on this relationship with the environment and with oneself.

The allotment of the structural components of the system of ecological self-consciousness determination to a large extent is based on the analysis of the components of self-consciousness of the individual, corrected for the uniqueness and exclusivity of this psychic phenomenon [2, p. 120].

Ecological self-consciousness is a hierarchical dynamic phenomenon, which has three levels: elemental, personal and spiritual. Structural-dynamic model of determination of ecological consciousness represents its hierarchical system: elemental level (awareness of itself as the part of the World, interaction on this basis with the environment); personal level (awareness of its place in the world, real cooperation with the other) and the spiritual level (integral display of the World by personality, semantic unity with it). The system interconnection of these three levels ensures the vital activity of the individual in the ecosystem [1, p. 334].

At each of the levels, ecological self-consciousness functions as a four component formation (affective, cognitive, connative, value-reflexive components). The content fullness of the components of environmental consciousness has the following characteristics: affective (emotional) reflects the emotional color of the attitude towards themselves and awareness of its place in the world; cognitive - contains the image of physical self, a representation of

\footnotetext{
${ }^{1}$ National Pedagogical Dragomanov University, Ukraine
} 
abilities, of its place in the world and of its personal qualities. The third component represents the active life position of the individual, its activities in accordance with the natural environment and the social environment in which it is located. Value-reflexive component of environmental self-consciousness realizes the semantic orientation of the personality in the World and the ability to appreciate their own experiences, attitudes, and behavior [3, p. 75].

Distinguish between age, sexual, demographic and professional (teaching) features of ecological consciousness and its factors in youth.

Exists such age features of compensation for ecological consciousness: a) in the early and mature adolescence there is an insufficient development of the value-reflexive component; b) in boys and girls there are significant positive age dynamics of indicators of the cognitive component; c) affective and connative components have an average level of development during adolescence.

Sexual features of ecological consciousness development: a) growth of the indicators of cognitive and connative components in boys during the early and mature adolescent; b) positive changes in the development of affective and connative components in girls are observed; c) consistently low indicators of value-reflexive component during adolescence in the studied in boys and girls.

The demographic features of the ecological consciousness development are revealed: young people living in the city have lower indicators of affective, cognitive and value-reflective components development of ecological selfconsciousness in comparison with their peers living in rural areas. Indicators of the connative component are higher in urban youth than in rural areas [4, p.194].

Professional orientation on the level of ecological consciousness development is established: in youth, the future profession of which belongs to the type «Human - human» (psychological specialties), the most developed was an affective component, and in youth, the future profession which in content corresponds to the types of professions «Human - Sign system» (economic specialties) and «Human - nature» (eco-directed specialties) - a connative component.

\section{References:}

1. Berns R. (2003) Chto takoe Ya-kontseptsiya. Psikhologiya samosoznaniya [What is I-concept. The psychology of self-awareness]. Samara: Bahrah-M. (in Russian)

2. Kalmukov A. A. (2009) Vvedenie v ekologicheskuyu psikhologiyu. Kurs lektsiy [Introduction to Environmental Psychology. Lecture course]. Moscow: MNEPY. (in Russian)

3. Kulaghyna Y. Ju., Koljuckyj V. N. (2008) «Vozrastnaya psikhologiya. Polnyy zhiznennyy tsikl razvitiya» [Age-related psychology. Full development life cycle]. Moscow. (in Russian)

4. Maksymenko S. D., Papucha M. V. (2011) Psykhologhija osobystosti [Personality psychology]. Kyiv: «KMM». 